\title{
ORIGINAL BILINGUAL PUBLICATION ON BANKING
}

DOI: $10.18267 /$ j.pep.580

\section{Pavla Klepková Vodová}

\section{Michal Mejstřík, Magda Pečená, Petr Teplý. Bankovnictví v teorii a praxi. Banking in Theory and Practice}

\section{Prague: Karolinum, 2014. ISBN 978-80-246-3680-7}

In 2014, the offer of specialized publications dealing with the issue of banking has increased by a rare and extraordinary book, prepared by the team of Michal Mejstrík, Magda Pečená and Petr Teplý. The book has an original concept of bilingual publication. The same text in Czech and English is offered on each double page. This publication is therefore not only a useful source of information, but an excellent material for the study of professional English as well.

The reviewed publication is divided into twelve chapters. Each of them consists of two parts: the first theoretical part is accompanied by a second practical part. The practical parts of the chapters suitably complement the text with solved and unsolved examples.

First chapter defines basic terms of financial markets: theoretical and empirical definition of money, structure and content of monetary aggregates in selected countries, the problem of time value of money, savings and investments. The important part of the chapter deals with financial markets, their key functions, types and dynamics. The text is properly complemented by detailed characteristics of the size and structure of the world's financial market and the nature of financial intermediation in the Czech Republic. After reading this chapter, it is appropriate to continue with Chapter I.S, in which further selected problems of financial mathematics are explained not only with the use of solved examples, but also with clear schemes.

Chapter 2 is devoted to basic principles of banking. The structure of the chapter is fully logical: the term bank is defined and functions of the banking sector are explained in the beginning of the chapter. Then the basic financial statements and banking operations are described. The second part of the chapter is devoted to evaluation of performance, profitability, efficiency and risks of banks. The text also contains detailed analysis of market segmentation and bank heterogeneity in the Czech Republic. The last part of the chapter focuses on institutions that compete with banks. Chapter II.S.A as a practical supplement describes more in detail the financial statements, accounting standards, measuring the financial health of the bank and individual financial ratios of banks. Chapter II.S.B deals with organizational issues in banks and different approaches to the corporate governance.

As the central banks play an important role in financial markets, Chapter 3 covers the issue of central banking and interest rates. Readers are acquainted with history, functions 
and instruments of central banks, transmission mechanism of monetary policy, money and deposit multiplier. The third part of the chapter is dedicated to interest rates, their time structure and theories of yield curves. Examples connected with money market instruments, interest rates and repurchase agreements are the content of the related Chapter III.S.

Risk measurement and management is an essential part of management. Therefore, in Chapter 4 the major banking risks are firstly defined, to be able then to focus on asset and liability management. It is also necessary to measure the achievement of the objectives of asset and liability management, e.g. with the use of risk index, net interest income margin or net income margin. The last part of the chapter deals with the basic model for the measurement of liquidity, currency and interest rate risk (i.e. gap analysis) and with development of yield curve. More detailed description of gap analysis, together with solved and unsolved examples for liquidity gap and interest rate gap, can be found in Chapter IV.S.

The title of Chapter 5 is banking regulation. Authors discuss the reasons for banking regulation, main aspects of banking sector regulation and supervision in the Czech Republic, together with the legislation. Authors slightly touched also the problem of the European banking union. Some areas of regulation and supervision are more described in other chapters; legal and numerical aspects of consolidation, mergers and acquisitions and methods of consolidation represent the content of Chapter V.S.

Both Chapter 6 and Chapter IV.S deal with banking capital. The theoretical Chapter 6 defines the difference between accounting, regulatory and economic capital and market capitalization; and makes readers familiar with selected theories of capital structure, some models dealing with the influence of deposit insurance on the value of the bank and the role of capital for banking credibility. Next part of the chapter focuses on the development of capital adequacy regulation from Basel I to Basel III. Instructions for calculation of capital adequacy are contained in a supplementary Chapter VI.S.

Issues concerning liquidity, liquidity risk and liability management are included in Chapter 7. Some types of deposit products are described in this chapter. After that, structure and volume of quick assets and net balance sheet position in the Czech Republic are analysed. The last part of this chapter is devoted to liquidity risk regulation under the new legislation rules Basel III. The supplementary Chapter IVV is very good. It comprises solved and unsolved examples for liability-side liquidity risk, asset-side liquidity risk, maturity laddering method and situation of liquidity distress. This makes much more possible to deeply understand the issue of liquidity risk.

Credit granting is one of the substances of banking business. Chapter 8 therefore focuses on credit risk, its sources and importance. Authors provide description of individual types of debt instruments by payments and repayments and by financing entities. In following subchapters, attention is paid to credit risk management in corporate and retail banking, and both macroeconomic and microeconomic approach to credit risk measurement and management. In the last part of the chapter, issues concerning rating, scoring, credit risk models and problem of loan pricing are mentioned. The last two issues are characterized in detail in Chapter VIII.S, which is very good as it clearly defines the principle of calculation with the use of examples.

The ninth chapter deals with methods for market risk measurement. Authors focused on volatility, sensitivity, duration, convexity, and very briefly on the Value at Risk 
method. The methods of market risk management, such as hedging and portfolio immunization, are also indicated. Chapter IX.S clearly clarifies individual methods of market risk measurement with the use of a large number of examples for duration, convexity and portfolio immunization. Especially valuable is the subchapter IX.5.2 which brings a comprehensive description of three methods for calculation of Value at Risk. Although this issue belongs to those more complex, readers can quite easily understand it.

The following two chapters are devoted to non-interest income of banks. In Chapter 10, authors focus on non-interest income resulting from payment transaction and off-balance sheet items. Also the types of payment system, structure and importance of individual payment instruments are analysed. The additional Chapter X.S then characterizes in detail selected credit derivatives and foreign exchange swaps. The principle of their using is again properly illustrated by solved examples.

Chapter 11 then focuses on non-interest income resulting from banks' financial and credit operations and financial innovations which means from cash-pooling, factoring, forfaiting, leasing and some less usual financial possibilities. As activities of investment banking may also be a source of non-interest income, the attention is paid also to securitization. The principle of price calculation for factoring and forfaiting are explained in additional Chapter XI.S.

The last chapter of the reviewed publication deals with the development of the banking sector as a financial services provider in the European Union. Authors firstly describe general and specific problems of economic transformation in order to pass through a process of consolidation of corporate governance to the current status of the banking sector in the European Union. Later they focus on financial consolidation and privatization of the banking sector in the new member states and on post-privatization phase in the banking sector. The last practical Chapter XII.S focuses on mergers and acquisitions, private equities investments, valuation techniques and exit strategies.

It is necessary to appreciate once again the unique concept of a bilingual publication. Authors of the publication define not only basic concepts and principles of banking; some parts of the publication actually solve the issue in detail and in depth, which makes the publication usable also for more advanced courses in banking.

The reviewed publication is a completely rewritten and updated edition of a previous book of the same team of authors (Základní principy bankovnictví/Basic principles of banking, published by Karolinum Press in 2008). The changes in the structure and text of the publication were really substantial: the new publication is more than 200 pages larger, authors significantly improved text of the publication according to recommendations of previous reviewers, and the entire text is far more consistent. The publication contains many tables and figures which documents the trends in banking sector development.

The publication Bankovnictví v teorii a praxi - Banking in theory and practice undoubtedly represents a qualitative shift in the literature of this kind. Surely it would become a welcome and exploited study text for students, doctoral students, teachers and researchers, as well as readers from practice. 